\title{
RFID Security and Privacy Enhancement
}

\author{
Jasmin M, Saravana.S, Kanagavalli.G.
}

\begin{abstract}
This paper aims in providing new technique to provide privacy and security. The parameters related to location will be considered for this.This information can be taken for defend measures to avoid unauthorized access.Secured schemes will be employed for transaction on server side.Our work focuses on using RFID tags with efficient sensing techniques.This methodology proves to be more secure as it is independent on man power and other devices.
\end{abstract}

Keywords : Location safe cards (LASE), RFID.

\section{INTRODUCTION}

System that has combination of both hardware and software targeted to do particular functionality is names as an embedded system. The application of this system is vast ranging from small appliances used in household activities to complicated electronic equipments. They are usually accompanied with interfacing facilities.

System that identifies frequency in the range of Radio Frequency are gaining more importance in both private and public sectors. Mobile equipment which is based on near field communication can be utilized to issue tokens for payments and these kind of technology will have a promising feature in the future. The tiny devices which act like Wireless equipments are named as tags. They act like a storage element. The content of information is usually receptive .To the queries raised to tags in the allotted frequency range appropriate reply will be given. The collected details will be given for data processing to the output device The obtained output is utilized for many tasks.[1-10]

Reader which is used in device for identifying radio frequency range forms a framework to extract information from tags. These tags contain antennas for communicating on both transmitter and reception side. Reader in the framework contains processors, modulating and demodulating devices. For this addressed issue proper authentication is required. To verify the functionalities of hardware we employ two GSM hardware. Once the GSM modem is activated it will verify the functionality of the hardware and it will stop the application. [11-15]

Position of the satellite is estimated by the receiver in Global positioning system. For this signals received by satellites are used.

1.2 Applications

- E- passport

- Credit card

Revised Manuscript Received on August 22, 2019.

Jasmin M, Assistant Professor, Department of Electronics And Communication Engineering,, Bharath Institute of Higher Education and Research, Chennai, India.rifriz@gmail.com

Saravana.S, Assistant Professor, Department of Electronics And Communication Engineering,, Bharath Institute of Higher Education and Research, Chennai, India . selvidurai1975@gmail.com

Kanagavalli. Assistant Professor, Department of Electronics And Communication Engineering,, Bharath Institute of Higher Education and Research, Chennai, India. kanags89@gmail.com

\section{- Drivere's license}

\section{A. Proposed MPLAB IDE}

MPLAB IDE is an integrated planning environment that gives development engineers the versatility to create and debug firmware for numerous Microchip operating systems.

MPLAB IDE is a Windows-based Integrated Development Environment for Microchip Technology Incorporated PIC Microcontrollers (MCU) and PIC Digital Signal Controllers (DSC) families. MPLAB SIM is a discrete event simulator for families with PIC microcontrollers (MCUs).. It is integrated into the incorporated computing environment of MPLAB IDE. The MPLAB SIM coding tool is intended to model the procedure of the Microchip Technological innovation PIC embedded systems to assist users in configuring software for these systems.. Both methods are used in the extraction of multilayer panels. The internal coats are reproduced and etched whereas the filaments stay printed, plated and etched after tapping the inner layers.

\section{B .In the MPLAB IDE, you can:}

- Gather, annotate and link the source code using a variety of language tools. The assembler, linker and librarian are provided with MPLAB IDE. C compilers are obtainable from Microchip and other third party suppliers..

- Troubleshoot the executable rationale by watching system stream with a test system, for example, MPLAB SIM, or progressively with an emulator, for example, MPLAB ICE. Outsider emulators that work with MPLAB IDE are likewise accessible.

- Make timing estimations.

- View factors in Watch windows. [16]

- Program firmware into gadgets with software engineers, for example, PICSTART Plus or PRO MATE II.

- Find fast responses to inquiries from the MPLAB IDE on-line Help[17]

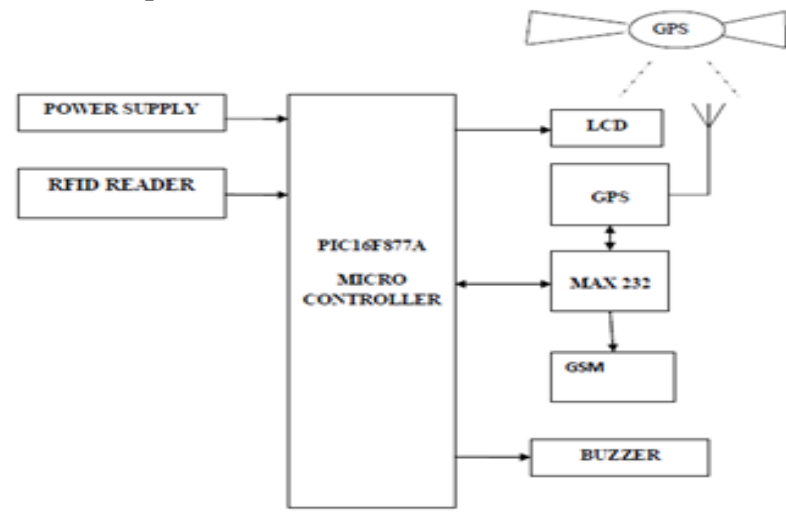

Fig. 1 Block diagram of proposed location sensing by RFID security system

Microcontroller started the advancement of transistor technology. This advancement

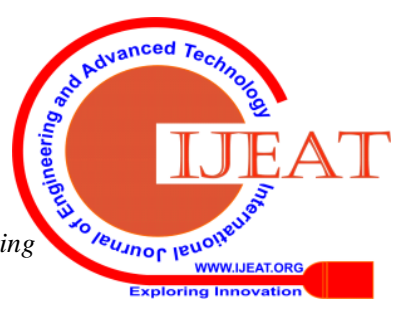


has provided the opportunity to store hundreds of thousands of transistors in a single Chip, . The microcontroller is the actual chip computer.[18]

The layout involves all the development characteristics of the microcontroller, such as CPU, ALU, PC, SP and records.It also needs some functionalities desired to make a comprehensive ROM, RAM, parallel I / O, serial I / O, counter and clock circuit. The primary practice of a microcontroller is to regulate the process of a engine spending a specified database that is accessed in the ROM and ensures not alter above the life of the system. The architectural style and practical training Set up of the microcontroller is where microcontroller programs involve regulate process, design process and medicine.[19]

These transistors included both the operating system and the devices. This chip is called as microcomputer or later it would be known as microcontroller. It includes input and output ports, memory, timer, etc. The logic analyzer is a specific type of microcontroller and integrates the modules of the microprocessor that take part in a single break and builds a single imaging system. It includes the fundamental central processing unit, the input / output peripheral, and these microcontrollers need a policy to store information from inputs. The major cause to use microcontroller is the cost and quick to get. Even though it has multiple solicitations, the price is more cheaply compared to complex circuit such as IC MC14528B.[20]

Fig. 2 Architecture of PIC Microcontroller configured Manage information in bit and byte size. Areas

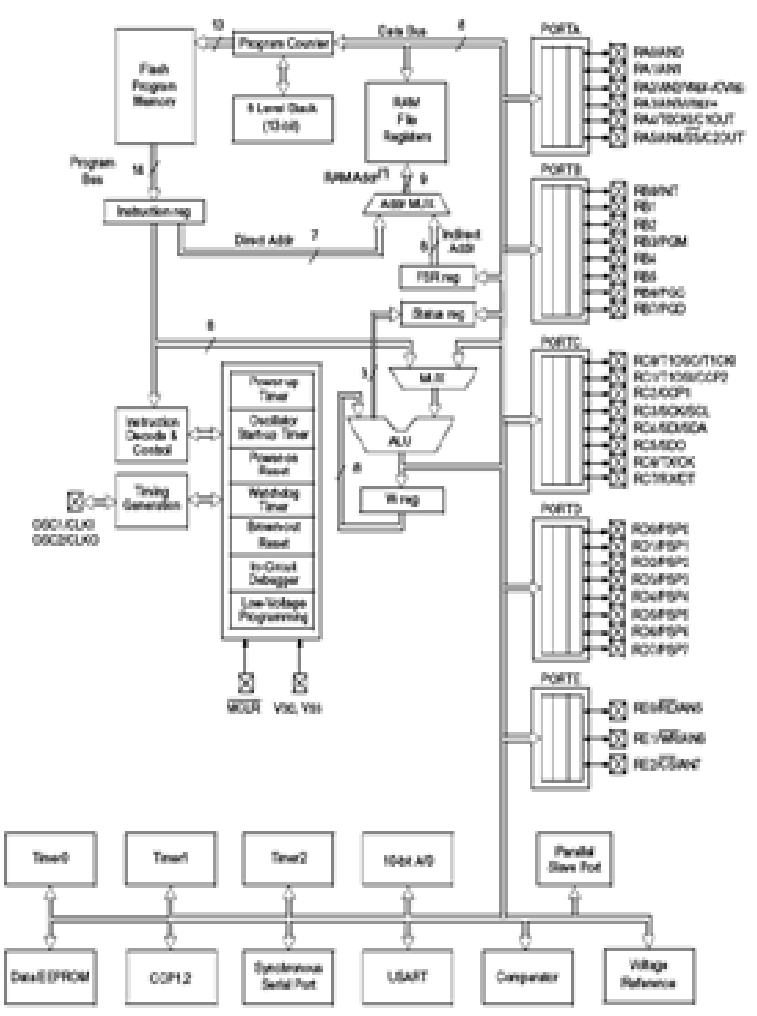

\section{RESULT ANALYSIS}

Authors deliver their graduate to Govt. of Indiaand Step 1

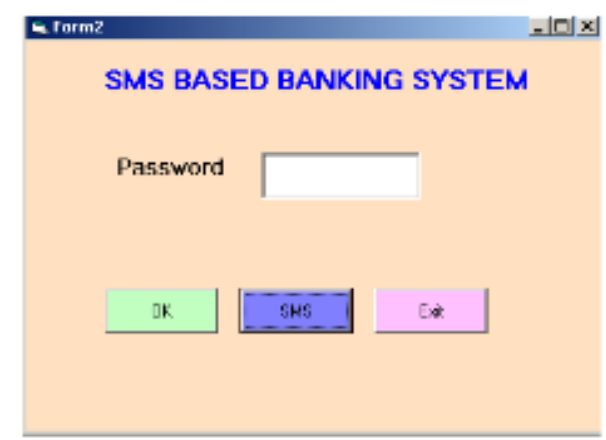

The SMS based banking system is used to intimate the original user mobile phone through the SMS. So we have to enter the password of the card.

Step 2:

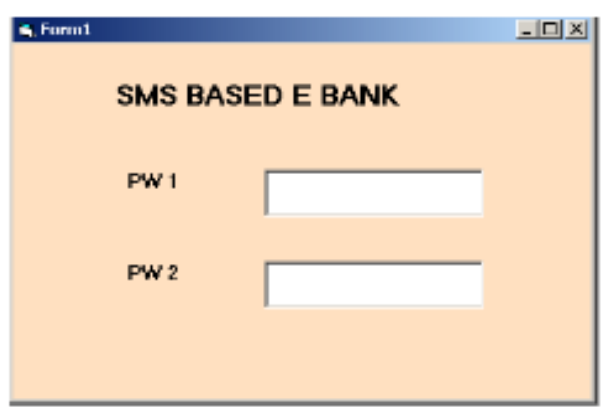

Step 3

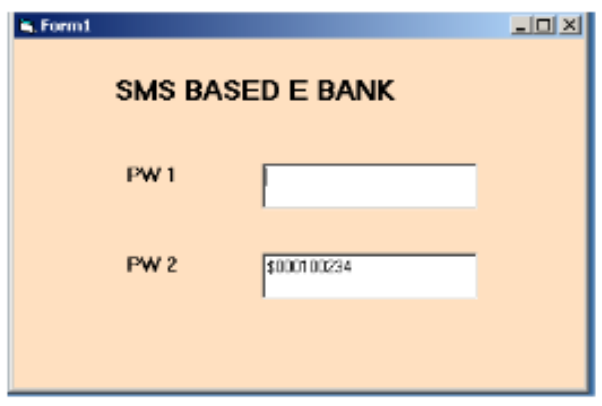

In this, after entering the password it should be matched with the password 1, what we enter already in the SMS based E bank.AC voltage of $230 \mathrm{~V}$ is utilized as a power source. For requirement of minimum voltage and current we employ step down transformer.

As the circuits works on DC the output AC voltage has to be converted to DC.We utilize rectifiers that contains diodes in bridge formatfor this conversion. So rectifier circuit is used to convertAC to DC[19]

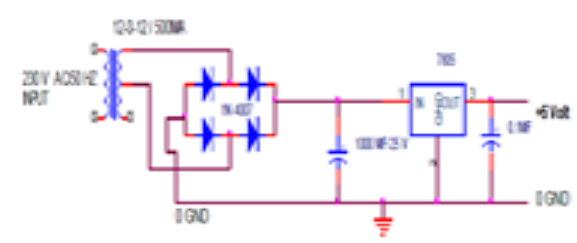

Fig. 3 Circuit Diagram of Power Supply 


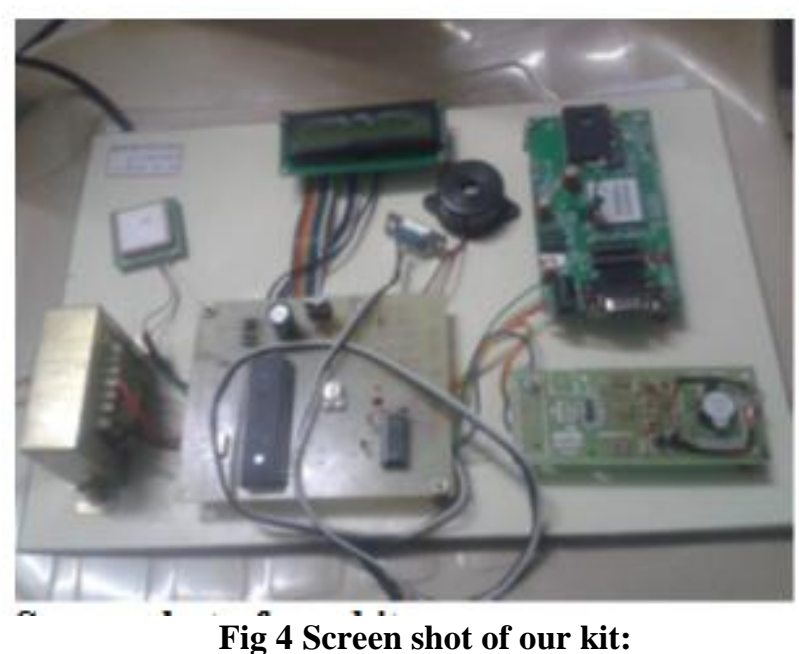

\section{CONCLUSION}

RFID is one of the best technology used for information exchange. Here Security is achieved by considering the locality parameters. and it is very economical too. Future work lies in the optimization of algorithm to enhance the accuracy. Also RFID tags wii be substituted by Near Field Communication In future advanced sensors will be used to determine near by places based on location-specific sensor information

\section{REFERENCES}

1. Gowri Sankaran, B., Karthik, B. \& Vijayaragavan, S.P. 2019, "Weight ward change region plummeting change for square based image huffman coding", International Journal of Innovative Technology and Exploring Engineering, vol. 8, no. 10, pp. 4313-4316.

2. Gowri Sankaran, B., Karthik, B. \& Vijayaragavan, S.P. 2019, "Image compression utilizing wavelet transform", International Journal of Innovative Technology and Exploring Engineering, vol. 8, no. 10, pp. 4305-4308.

3. Kandavel, N. \& Kumaravel, A. 2019, "Offloading computation for efficient energy in mobile cloud computing", International Journal of Innovative Technology and Exploring Engineering, vol. 8, no. 10, pp. 4317-4320.

4. Vinoth, V.V. \& Kanniga, E. 2019, "Reversible data hiding in encrypting images-an system", International Journal of Engineering and Advanced Technology, vol. 8, no. 6, pp. 3051-3053.

5. Selvapriya, B. \& Raghu, B. 2019, "Pseudocoloring of medical images: A research", International Journal of Engineering and Advanced Technology, vol. 8, no. 6, pp. 3712-3716.

6. Senthil Kumar, K. \& Muthukumaravel, A. 2019, "Bi-objective constraint and hybrid optimizer for the test case prioritization", International Journal of Engineering and Advanced Technology, vol. 8, no. 6, pp. 3436-3448.

7. Kavitha, G., Priya, N., Anuradha, C. \& Pothumani, S. 2019, "Read-write, peer-to-peer algorithms for the location-identity split", International Journal of Innovative Technology and Exploring Engineering, vol. 8, no. 9 Special Issue 3, pp. 445-447.

8. Kaliyamurthie, K.P., Michael, G., Anuratha, C. \& Sundaraj, B. 2019, "Certain improvements in alzheimer disease classification using novel fuzzy c means clustering for image segmentation", International Journal of Innovative Technology and Exploring Engineering, vol. 8, no. 9 Special Issue 3, pp. 599-604.

9. Kaliyamurthie, K.P., Sundarraj, B., Geo, A.V.A. \& Michael, G. 2019, "RIB: Analysis of I/O automata", International Journal of Innovative Technology and Exploring Engineering, vol. 8, no. 9 Special Issue 3, pp. 1019-1022.

10. Velvizhi, R., Rajabhushanam, C. \& Vidhya, S.R.S. 2019, "Opinion mining for travel route recommendation using Social Media Networks (Twitter)", International Journal of Innovative Technology and Exploring Engineering, vol. 8, no. 9 Special Issue 3, pp. 508-512.
11. Kavitha, R., Sangeetha, S. \& Varghese, A.G. 2019, "Human activity patterns in big data for healthcare applications", International Journal of Innovative Technology and Exploring Engineering, vol. 8, no. 9 Special Issue 3, pp. 1101-1103.

12. Pothumani, S., Anandam, A.K., Sharma, N. \& Franklin, S. 2019, "Extended VEOT framework - Implemented in a smart boutique", International Journal of Innovative Technology and Exploring Engineering, vol. 8, no. 9 Special Issue 3, pp. 762-767.

13. Kaliyamurthie, K.P., Michael, G., Krishnan, R.M.V. \& Sundarraj, B. 2019, "Pseudorandom techniques for the internet", International Journal of Innovative Technology and Exploring Engineering, vol. 8, no. 9 Special Issue 3, pp. 915-918.

14. Aravindasamy, R., Jeffrin Rajan, M., Rama, A. \& Kavitha, P. 2019, "Deep learning provisions in the matlab: Focus on CNN facility", International Journal of Innovative Technology and Exploring Engineering, vol. 8, no. 9 Special Issue 3, pp. 990-994.

15. Theivasigamani, S., Linda, M. \& Amudha, S. 2019, "Object sensing and its identification \& motion sensing", International Journal of Innovative Technology and Exploring Engineering, vol. 8, no. 9 Special Issue 3, pp. 545-549.

16. Mary Linda, I., Vimala, D. \& Shanmuga Priya, K. 2019, "A methodology for the emulation of IPv4", International Journal of Innovative Technology and Exploring Engineering, vol. 8, no. 9 Special Issue 3, pp. 848-852.

17. Velvizhi, R., Priya, D.J., Vimala, D. \& Linda, I.M. 2019, "Increased routing algorithm for mobile adhoc networks", International Journal of Innovative Technology and Exploring Engineering, vol. 8, no. 9 Special Issue 3, pp. 1606-1608.

18. Sangeetha, S., Anuradha, C. \& Priya, N. 2019, "DNS in real world", International Journal of Innovative Technology and Exploring Engineering, vol. 8, no. 9 Special Issue 3, pp. 937-940.

19. Geetha, C., Vimala, D. \& Priya, K.S. 2019, "Constructing multi-processors and spreadsheets with SKIVE", International Journal of Innovative Technology and Exploring Engineering, vol. 8, no. 9 Special Issue 3, pp. 516-519.

20. Yugendhar, K., Sugumar, V. \& Kavitha, P. 2019, "A novel method of univac using fuzzy logic", International Journal of Innovative Technology and Exploring Engineering, vol. 8, no. 9 Special Issue 3, pp. $435-437$.

21. Kaliyamurthie, K.P., Michael, G., Elankavi, R. \& Jijo, S.A. 2019, "Implementing aggregate-key for sharing data in cloud environment using cryptographic encryption", International Journal of Innovative Technology and Exploring Engineering, vol. 8, no. 9 Special Issue 3, pp. 957-959.

22. Jeffrin Rajan, M., Aravindasamy, R., Kavitha, P. \& Rama, A. 2019, "A novel method of object orientation variation in $\mathrm{C}++$ and java", International Journal of Innovative Technology and Exploring Engineering, vol. 8, no. 9 Special Issue 3, pp. 708-710.

23. Nayak, R., Dinesh, S. \& Thirunavukkarasu, S. 2019, "A novel method improvement of rapid miner for the data mining applications", International Journal of Innovative Technology and Exploring Engineering, vol. 8, no. 9 Special Issue 3, pp. 457-460.

24. Sivaraman, K., Krishnan, R.M.V., Sundarraj, B. \& Sri Gowthem, S. 2019, "Network failure detection and diagnosis by analyzing syslog and SNS data: Applying big data analysis to network operations", International Journal of Innovative Technology and Exploring Engineering, vol. 8, no. 9 Special Issue 3, pp. 883-887.

25. Vimala, D., Linda, I.M. \& Priya, K.S. 2019, "Decoupling online algorithms from erasure coding in DNS", International Journal of Innovative Technology and Exploring Engineering, vol. 8, no. 9 Special Issue 3, pp. 950-953.

26. Rama, A., Kumaravel, A. \& Nalini, C. 2019, "Preprocessing medical images for classification using deep learning techniques", International Journal of Innovative Technology and Exploring Engineering, vol. 8, no. 9 Special Issue 3, pp. 711-716.

27. Sangeetha, S., Srividhya, S.R., Anita Davamani, K. \& Amudha, S. 2019, "A procedure for avoid overrun error in universal synchronous asynchronous receiver transmitter (usart) by utilizing dummy join and interrupt latency method", International Journal of Innovative Technology and Exploring Engineering, vol. 8, no. 9 Special Issue 3, pp. 657-660.

28. Aravindasamy, R., Jeyapriya, D., Sundarajan, B. \& Sangeetha, S 2019, "Data duplication in cloud for optimal performance and security", International Journal of Innovative Technology and Exploring Engineering, vol. 8, no. 9 Special Issue 3, pp. 1156-1158. 
29. Aravindasamy, R., Jeffrin Rajan, M., Sugumar, V. \& Kavitha, P. 2019, "A novel method on developing superblocks and the transistor using apodryal", International Journal of Innovative Technology and Exploring Engineering, vol. 8, no. 9 Special Issue 3, pp. 982-985.

30. Sasikumar, C.S. \& Kumaravel, A. 2019, "E-learning attributes selection through rough set theory and data mining", International Journal of Innovative Technology and Exploring Engineering, vol. 8, no. 10 , pp. $3920-3924$

\section{AUTHORS PROFILE}

Jasmin .M Assistant Professor, Department of Electronics And Communication Engineering,, Bharath Institute of Higher Education and Research, Chennai, India.

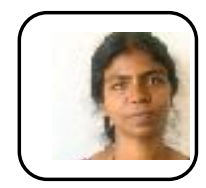

Saravana.S, Assistant Professor, Department of Electronics And Communication Engineering,, Bharath Institute of Higher Education and Research, Chennai, India.

Kanagavalli. Assistant Professor, Department of Electronics And Communication Engineering,, Bharath Institute of Higher Education and Research, Chennai, India.kanags89@gmail.com 